\title{
THE USE OF ONLINE LITERATURE CIRCLES TO ENHANCE THE STUDENTS' CRITICAL READING SKILL
}

\author{
${ }^{1,2}$ Titi Rokhayati, ${ }^{1}$ Erna Alvionita \\ ${ }^{1}$ FKIP, Purworejo Muhammadiyah University, Indonesia \\ ${ }^{2}$ Co. Author Email: trokhayati@umpwr.ac.id
}

\begin{tabular}{|c|c|}
\hline Article Info & Abstract \\
\hline $\begin{array}{l}\text { Article History } \\
\text { Received: October } 2021 \\
\text { Revised: December } 2021 \\
\text { Published: January } 2022\end{array}$ & $\begin{array}{l}\text { This research aims to find out whether using Online Literature Circles to } \\
\text { enhance the student's critical reading skills is effective or not. This research } \\
\text { belongs to quantitative research using a pre-experimental design. The population } \\
\text { of this research is eleventh-grade students of SMK } N 1 \text { Puring in the academic }\end{array}$ \\
\hline $\begin{array}{l}\text { Keywords } \\
\text { Critical Reading; } \\
\text { Online Literature Circles; }\end{array}$ & $\begin{array}{l}\text { year of 2020/2021 which consists of } 382 \text { students. The sample of this research is } \\
\text { XI TKPI } 1 \text { consist of } 34 \text { students. The data were taken virtual from } 17 \text { th May } \\
2021 \text { to } 31 \text { st May } 2021 \text {. The technique of the data collection is using a test. It was } \\
\text { done by giving an online pre-test and online post-test. Meanwhile, the technique } \\
\text { of data analysis used descriptive analysis and inferential analysis. The result of } \\
\text { this research shows that the mean score of the pre-test is } 49.79 \text { which belongs to } \\
\text { fairly sufficient category, and the mean score of the post-test is } 70.79 \text { which } \\
\text { belongs to the good category. To see whether the hypothesis is accepted or } \\
\text { rejected, the researchers use t-test through IBM SPSS } 25 \text {. The result two-sided } \\
\text { significant value is O.000. Based on the 0.05 significant level, the computation } \\
\text { shows the two-sided significance value is lower than 0.05 (0.000<0.05). } \\
\text { Therefore, it can be concluded that Online Literature Circles is effective to } \\
\text { enhance the students' critical reading skills at the eleventh-grade students of } \\
\text { SMK } N 1 \text { Puring in the academic year of } 2020 / 2021 \text {. }\end{array}$ \\
\hline
\end{tabular}

How to cite: Rokhayati, T. \& Alvionita, E. (2022). The use of online literature circles to enhance the students' critical reading skill, JOLLT Journal of Languages and Language Teaching, 10(1), pp. 94-101. DOI: https://doi.org/10.33394/jollt.v\%vi\%i.4079

\section{INTRODUCTION}

The four language skills which must be acquired by students are listening, reading, writing, and speaking. Listening and reading are receptive skills while speaking and writing are productive skills. To master all those skills, a student should master reading. Reading is considered as an important skill as the result of PISA on literacy, Indonesia was in 72 ranks with the score 371(https://litbang.kemdikbud.go.id/pisa) thus the literacy should be improved.

Reading ability in higher education is a must since it is used for finding many things in the textbook either hard or softcopy or even virtually. The trend nowadays is understanding reading not just for accomplishing the $5 \mathrm{~W}$ and $1 \mathrm{H}$ but also to deepen our understanding of the text by having HOTS (High Order Thinking Skills). Teachers in Indonesia are required under the 2013 curriculum to promote students' Higher Order Thinking Skills (HOTS). One of the learning objectives of HOTS is for students to be able to assess, evaluate, and construct their knowledge. However, there is few research on HOTS issues in English learning, notably in reading skills. Reading becomes more significant than other skills for Indonesian students since they cannot have direct native discussions and have more access to written materials. Academic life will become easier if students' reading skills are adequate. Students can also learn to appreciate the beauty of language.

According to the World Bank (UNESCO, 2012), a growing number of developing countries have been measuring the reading skills of students in early primary school since 2008. This is to show how important this skill is for personal achievement as well as society 
as a whole, and how ignorance of this critical skill, especially in the early grades, leads to a lot of learning issues. Students who are unable to read lack the required skills for successful learning in later grades. Related to the problems of reading, Davison, and Dowson in Ranggi (2019) state that there are three strategies for teaching reading, that are individual class, group class, and whole class. Group classes allow students to discuss their responses to the text in a small group of students. Individual classes allow students to engage with text because they are allowed to read their own choice of books. While the whole class strategy allows students to read aloud to the class. Co-operative learning is a successful teaching strategy in which small teams use a variety of learning activities to improve their understanding of a subject (Kagan as cited in Kasim, 2011).

There are kinds of reading, they are intensive, extensive, and critical reading. Critical reading is the greatest level of reading behavior. Students must be able to read critically both non-fiction and fiction materials at this level of reading. Students must be able to comprehend the text as its whole, not only the major theme, the text's content, or the language used in the text.

Critical reading, according to Wang \& Gierl (2011:169), entails a higher level of thinking in which the reader employs a questioning attitude, logical analysis, and intervention to assess the value of what is read. As a result, the students should have become more engaged. These skills can be summed up as critical reading, in which students engage in a process of analyzing, interpreting, and, in some cases, rewriting. On the other hand, many students struggle with critical reading. Similarly, the findings of a study conducted by Zin and Eng (2014) support the assumption that Asian students are often non-critical readers and thinkers. Based on an identification done by Wallace (2003:4) as cited in Rohmah (2018), students did not get sufficient exposure to experience critical reading. It was due to the following causes; limited time allocation, large classes, teachers' knowledge, and students' reading habit. It is still problematic for the students to obtain critical reading skills and it needs big efforts and time to train the students to be critical. This is also due to the lack of student motivation in the lecture process.

To solve the problem of critical reading ability the researchers used Literature Circles as an active way to improve the critical reading skills of students, enhancing the communication between students, and giving individual students an active role in the learning process because they have to focus on the task given them.

Literature Circles is a reading strategy that draws on some principles: students read their self-selected text from multiple texts that link and expand concepts, by which they can be more engaged in reading and be more motivated as well as get a vocabulary-rich environment; share their responses in small group discussion; and then share the responses with the whole class (Daniels as cited in Irawati, 2016). Daniels (1994) says that Literature Circles is temporary discussion groups made up of students who are reading the same piece of literature and have particular roles during the sessions. Additionally, Furr (2004) states that EFL Literature Circles are fun and interesting. This strategy allows students to have a leader in group discussion, a summary, a master word, a connector, a collector culture, and a picker in each group. The activities support not only the group, but also each student by increasing encouragement, providing opportunities for critical thinking, and teaching students how to collaborate. Due to the COVID-19 outbreak, the researcher has adapted virtually literature circles. It can be concluded that the objective of the research is to see whether the use of literature circles to enhance students' critical reading is effective or not.

\section{RESEARCH METHOD} Research Design 
This study use pre-experimental research design by using pre-test and post-test with quantitative approach. The researchers want to establish possible cause and effect between dependent and independent variable. This research is about the use of online Literature Circles to enhance the students' critical reading skill at the eleventh grade of SMK N 1 Puring in the academic year 2020/2021. The researchers compare the students' score before being taught by using Online Literature Circles and after being taught by using Online Literature Circles. The treatment was done virtually through Zoom Aplication. The researchers have three cycle of Online Literature Circles. This research classified as pre experimental design because it had not a control variable. In this research, the researcher just put one group and use pretest and post-test to see the effect of the treatment.

\section{Population and Sample}

The researcher choose the eleventh grade students of SMK N 1 Puring in the academic year of 2020/2021 as her research population. The total number of the students is 382 students. They were grouped into 12 classes. In this research, the researchers use purposive sampling. The reason of the researcher in choosing this sampling technique is because of the limitation of the time, energy, and budget. The researchers cannot hold a long time to do the research in the school and the researcher has a very limit budget to do the research.the researcher took one class of the eleventh grade students of SMK N 1 Puring as the sample, which is XI TKPI 1.

\section{Instruments}

The instrument of this research is test. The researchers give online pre-test and post-test of critical reading which consisted of 30 multiple choice questions. The questions of post-test was different from the question of pre-test. The pre-test and post-test was done online by using Google Forms application.

\section{Data Analysis}

Data analysis is the process of arranging data sequence, organize into a system, category and set of the breakdown of base. In this research, after held the study, pre-test, treatment, and post-test, the researchers then analyzing the result in quantitative way. The data from test will be analyzed by using calculating the improvement of the student score in the pre-test and post-test. To interpret the result of the students' test, the researchers used statistical procedures includes descriptive analysis and inferential analysis. The descriptive analysis includes mean, median, mode, standard deviation, and variance. The inferential analysis in this research consists of test of normality and test of hypothesis. The inferential analysis is employed to provide an answer to the questions of whether or not there is any and significant effect of using online Literature Circles on students' critical reading skill. The researcher employs parametric statistics ( $t$-test formula) because the data have normal distribution. To analyze the data, the analytical software package IBM SPSS 25 was used.

\section{RESEARCH FINDINGS AND DISCUSSION Research Findings}

The result of pre-test and post-test was distributed based on the classification of students' achievement by Arikunto (2010:184). It was shown in the following table:

Table 1

Classification on the Students' Score in Pre-test and Post-test

\begin{tabular}{llllll}
\multirow{2}{*}{ Value } & \multirow{2}{*}{ Level of Achievement } & \multicolumn{2}{c}{ Pre-test } & \multicolumn{2}{c}{ Post-test } \\
\cline { 3 - 6 } & & Frequency & Percentage & Frequency & Percentage \\
\hline $80-100$ & Excellent & 0 & $0 \%$ & 5 & $14.71 \%$ \\
\hline $66-79$ & Good & 1 & $2.95 \%$ & 17 & $50 \%$
\end{tabular}




\begin{tabular}{llllll}
$56-65$ & Sufficient & 6 & $17.65 \%$ & 12 & $35.29 \%$ \\
\hline $40-55$ & Fairly Sufficient & 25 & $73.52 \%$ & 0 & $0 \%$ \\
\hline$<39$ & Low & 2 & $5.88 \%$ & 0 & $0 \%$ \\
\hline Total & & 34 & $100 \%$ & 34 & $100 \%$
\end{tabular}

From the table above, it showed the result of students' critical reading skill pre-test and post-test done by XI TKPI 1 . In the pre-test, no student $(0 \%)$ belonged to excellent level, 1 student $(2.95 \%)$ belonged to good level, 6 students $(17.65 \%)$ belonged to sufficient level, 25 students $(73.52 \%)$ belonged to fairly sufficient level, and 2 students $(5.88 \%)$ belonged to low level. In the post-test, 5 students $(14.71 \%)$ belonged to excellent level, 17 students $(50 \%)$ belonged to good level, 12 students $(35.29 \%)$ belonged to sufficient level, no student $(0 \%)$ belonged to fairly sufficient level, and no student $(0 \%)$ belonged to low level. The research findings of pre-test and post-test were also described into the form of chart, it was presented in the following:
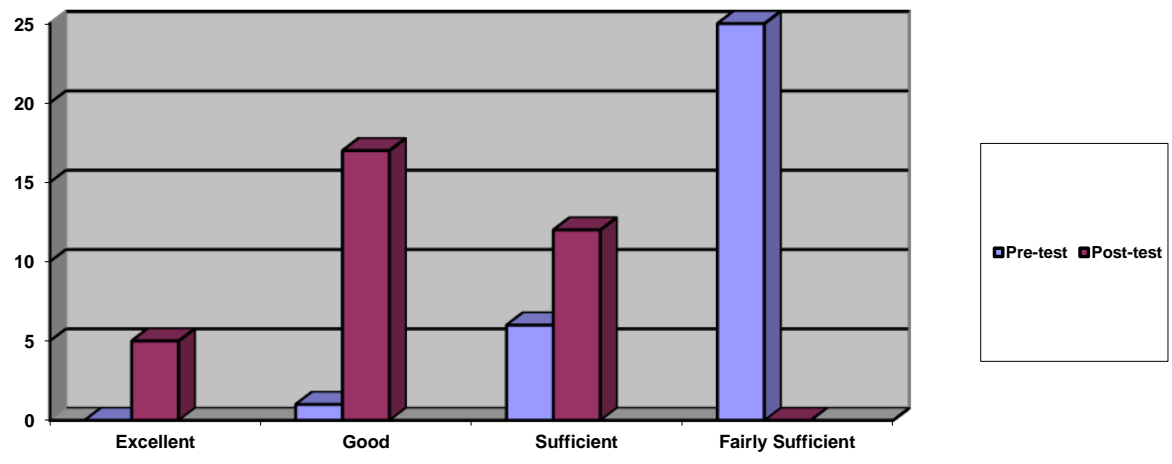

Figure 1. Results of Pre-test and Post-test

The researchers would go over the data from the sample in depth in this stage. The data was computed using the central tendency, which includes the mean, median, and mode. Meanwhile, the researcher calculated the range, variance, and standard deviation of the group variance.The researchers used IBM SPSS 25 for statistics analysis, the result of statistics analysis was in the table below.

Table 2

Descriptive Statistic 


\begin{tabular}{|c|c|c|c|}
\hline \multicolumn{4}{|c|}{ Statistics } \\
\hline & & Pre_test & Post_test \\
\hline \multirow[t]{2}{*}{$N$} & Valid & 34 & 34 \\
\hline & Missing & 0 & 0 \\
\hline \multicolumn{2}{|c|}{ Mean } & 49.79 & 70.79 \\
\hline \multicolumn{2}{|c|}{ Median } & 49.00 & 70.00 \\
\hline \multicolumn{2}{|c|}{ Mode } & 46 & $64^{\mathrm{a}}$ \\
\hline \multicolumn{2}{|c|}{ Std. Deviation } & 8.779 & 8.463 \\
\hline \multicolumn{2}{|c|}{ Variance } & 77.078 & 71.623 \\
\hline \multicolumn{2}{|c|}{ Range } & 39 & 30 \\
\hline \multicolumn{2}{|c|}{ Minimum } & 34 & 58 \\
\hline \multicolumn{2}{|c|}{ Maximum } & 73 & 88 \\
\hline \multicolumn{2}{|c|}{ Sum } & 1693 & 2407 \\
\hline
\end{tabular}

The researchers found that the mean of pre-test score was 49.79 while the mean of post-test score was 70.79. The median of pre-test was 49 and the median of post-test was 70 . The mode of pre-test was 46 and the mode of post-test was 64 . The standard deviation of pretest was 8.78 while the standard deviation of post-test was 8.46. The variance of pre-test was 77.08 and the variance of post-test was 71.62. Moreover, the range of pre-test was 39 and the range of post-test was 30 .

In answering the hypothesis, the researchers employed inferential analysis. The inferential analysis includes the test of normality and test of hypothesis. In testing the normality of the data, the researchers used IBM SPSS 25 by applied Kolmogorov-Smirnov normality test. The computation of normality test using IBM SPSS 25 can be seen in the table below.

Table 3

Test of Normality Kolmogorov-Smirnov

\begin{tabular}{|c|c|c|c|c|c|c|c|}
\hline \multicolumn{8}{|c|}{ Tests of Normality } \\
\hline & \multirow[b]{2}{*}{ Test } & \multicolumn{3}{|c|}{ Kolmogorov-Smirnov ${ }^{a}$} & \multicolumn{3}{|c|}{ Shapiro-Wilk } \\
\hline & & Statistic & df & Sig. & Statistic & df & Sig. \\
\hline \multirow[t]{2}{*}{ Score } & Pre_test & .138 & 34 & .101 & .966 & 34 & .371 \\
\hline & Post_test & .142 & 34 & .080 & .953 & 34 & .152 \\
\hline
\end{tabular}

According to Field (2012: 182), the data can be said normal if the significance value is higher than significance level $(>0.05)$. Then, the data can be said abnormal if the significance value is lower than significance level $(<0.05)$. The computation above showed in the Kolmogorov-Smirnov column that the significance value of pre-test was 0.101 and the significance value of post-test was 0.080 . Both of the significance values were higher than 0.05. Thus, it can be concluded that the data distribution of pre-test and post-test was normal.

After knowing that the data distribution was normal, the researcher computed the test of hypothesis using IBM SPSS 25 by applied t-test. The result of t-test was as follows: 
Test of Hypothesis Using IBM SPSS 25

\begin{tabular}{|llr|}
\hline \multicolumn{2}{c}{ Paired Samples Test } & \\
& & $\begin{array}{c}\text { Pair 1 } \\
\text { Pre Test - } \\
\text { Post Test }\end{array}$ \\
\hline Paired Differences & Mean & -21.000 \\
\cline { 2 - 4 } & Std. Deviation & 9.853 \\
\cline { 2 - 4 } & Std. Error Mean & 1.690 \\
\cline { 2 - 4 } & $\begin{array}{l}\text { 95\% Confidence Interval } \\
\text { of the Difference }\end{array}$ & -24.438 \\
\cline { 2 - 4 } & Lower & -17.562 \\
\hline $\mathrm{t}$ & Upper & -12.427 \\
\hline df & One-Sided $p$ & 33 \\
\hline Significance & Two-Sided $p$ & $<.001$ \\
\hline
\end{tabular}

From the Table 4, the researchers found that the two sided significance value was 0.000. Before the experiment was conducted, the level of significance to use has been decided. The researcher used 5\% (0.05) significance level. Moreover, the two sided significance value was lower than $0.05(0.000<0.05)$. Based on the hypothesis testing, it means that Ho was rejected and $\mathrm{Ha}$ was accepted. The researchers concluded that there that using Online Literature Circles was effective to improve the students' critical reading skill.

\section{Discussion}

The researcher discussed the result of the students' critical reading skill and the effectiveness of using Online Literature Circle to improve students' critical reading skill. From the pre-test result of XI TKPI 1 of SMK N 1 Puring, it was stated that the highest score of pre-test was 73 and the lowest was 34 . The mean of pre-test was 49.79 , the standard deviation was 8.78, and the variance was 77.08. The mean score was included in the interval of 40 to 55. It means that the students of XI TKPI 1 of SMK N 1 Puring in the academic year of 2020/2021 have fairly sufficient result on their critical reading pre-test. In the class, students are asked to read various texts to encourage students to think critically. It is in line with Eliata and Miftakh (2021) who state providing students with various texts enable them to acquire broad insight and acquire various sentence patterns and vocabulary.

In this study, from 34 samples, no students $(0 \%)$ belonged to excellent level, 1 student $(2.95 \%)$ belonged to good level, 6 students $(17.65 \%)$ belonged to sufficient level, 25 students (73.52\%) belonged to fairly sufficient level, and 2 students $(5.88 \%)$ belonged to low level. Whereas from the post-test result of XI TKPI 1 of SMK N 1 Puring, it was stated that the highest score of post-test was 88 and the lowest was 58. The mean of post-test was 70.79, the standard deviation was 8.46, and the variance was 71.62. The mean score was included in the interval of 66 to 79. It means that the students of XI TKPI 1 of SMK N 1 Puring in the academic year of 2020/2021 have good result on their critical reading post-test. This finding indicates students need to be facilitated with reading activities as much as possible to train them to comprehend texts. It happens not only for non-native speakers but also for native speakers (Hartatik el al., 2016). From 34 samples, there were 5 students $(14.71 \%)$ belonged to excellent level, 17 students (50\%) belonged to good level, 12 students $(35.29 \%)$ belonged to sufficient level, no student $(0 \%)$ belonged to fairly sufficient level, and no student $(0 \%)$ belonged to low level. It means the students are in need to train to think critically toward texts 
being read (Thamrin \& Agustin, 2019; Aghanjani \& Gholamrezapour, 2019; Lee \& Chen, 2019).

Based on the presented data in the Table 4, it was shown that the result of the computation of two sided significance value was 0.000 . The researcher used the significance level 0.05. The computation shows that the two sided significance value was lower than significance level $(0.000<0.05)$. According to the result of data analysis, it was argued that using Online Literature Circles was effective to improve the students' critical reading skill at the eleventh grade students of SMK N 1 Puring in the academic year of 2020/2021. It means that there were significance differences between the pre-test and post-test results. Based on the computation of mean score, the value of mean score of post-test was higher than the mean score of pre-test $(70.79>49.79)$. Further, it was stated that using Online Literature Circle is effective to empower students' critical reading skill.

\section{CONCLUSION}

Referring to the results of the previous discussion, it can be concluded that the use of Online Literature Circles is effective to improve the students' critical reading skill. This idea is supported by the results of pre-test and post-test about students' critical reading skills. From the t-test computation, the result of two sided significance value is 0.000 . Being compared with 5\% significance level, the computation shows that two sided significance value is lower than $5 \%$ significance level $(0.000<0.05)$. Consequently, the alternative hypothesis $(\mathrm{Ha})$ is accepted. It means that using Online Literature Circle to improve the students' critical reading skill is effective. Future research have to consider another platform to bring Online Literature Circles since it may cause different result of the learning outcomes.

\section{REFERENCES}

Aghajani, M., \& Gholamrezapour, E. (2019). Critical thinking skills, critical reading and foreign language reading anxiety in Iran context. International Journal of Instruction, 12(4), 219-238. https://doi.org/10.29333/iji.2019.12414a

Arikunto, S. (2010). Prosedur Penelitian Suatu Pendekatan Praktik. Jakarta: Rineka Cipta.

Coccia, L., John, S., \& College, F. (2015). Literature Circles and Their Improvement of Comprehension How has open access to Fisher Digital Publications benefited you?

Eliata, N. M. A., \& Miftakh, F. (2021). Emphasizing text structure strategy instruction to scaffold 11th grade students' reading comprehension. Journal of Languages and Language Teaching, 9(4), 411. https://doi.org/10.33394/jollt.v9i4.3998

Furr, M. (2003). Why and how to use EFL literature circles.

Hartatik, Sri Fatmaning; Lestari, H. D. (2016). Reading experience non-native English speaking students majoring in English language teaching. JEES (Journal of English Educators Society), 1(October), 105-114. https://doi.org/10.21070/jees.v1i

Irawati, D. (2016). Effectiveness of Literature Circles on Students' Reading Comprehension. IJOLTL: Indonesian Journal of Language Teaching and Linguistics, 1(3), 179. https://doi.org/10.30957/ijoltl.v1i3.183

Karatay, H. (2017). The Effect of Literature Circles on Text Analysis and Reading Desire. International Journal of Higher Education, 6(5), 65. https://doi.org/10.5430/ijhe.v6n5p65

Kasim, U. (2011). An overview of the implementation of cooperative learning. English Education Journal, 2, 2-5.

Lee, K., \& Chen, X. (2019). An emergent interaction between reading fluency and vocabulary in the prediction of reading comprehension among French immersion elementary 
students. Reading and Writing, 32(7), 1657-1679. https://doi.org/10.1007/s11145-0189920-Z

Rafi, M. F., Islam, A. F., \& Cahyani, D. A. (2021). The relationship between students' reading attitude with the result of reading comprehension. Journal of Languages and Language Teaching, 9(4), 512. https://doi.org/10.33394/jollt.v9i4.4008

Thamrin, N. R., \& Agustin, S. (2019). Conceptual variations on reading comprehension through higher order thinking skills (HOTS) strategy. ENGLISH REVIEW: Journal of English Education, 7(2). https://doi.org/10.25134/erjee.v7i2.1777.Received

UNESCO: Opportunities Lost: The Impact of Grade Repetition And Early School Leaving. UNESCO Institute for Statistics - 2012. Canada.

Wang, C \& Gierl, M.J. (2011). Using the attribute hierarchy method to make diagnostic inferences about examinees' cognitive skills in critical reading. Journal of Educational Measurement Summer, 48(2): 165-187

Widowati, D. R., \& Kurniasih, K. (2018). Critical Reading Skill and Its Implication To Speaking Ability in Multicultural Classroom. A Journal of Culture English Language $\begin{array}{lllll}\text { Teaching Literature } \quad \& \quad \text { Linguistics, } & 5(2), & 18 .\end{array}$ https://doi.org/10.22219/celticumm.vol5.no2.18-23

Zin, Z. M. \&Eng, W. B. (2014). Relationship Between Critical Thinking Dispositions and Critical Reading Skills of Malaysian ESL Learners. The Asian EFL Journal Quarterly, 16 (3): 41-68. 